\title{
Bio-Methane Production from Maize with Varying Nitrogen Levels and Harvesting Times under Semi-Arid Conditions of Pakistan
}

\author{
Athar Mahmood ${ }^{1 *}$, Xiukang Wang ${ }^{2 * *}$, Asad Ali ${ }^{1}$, Masood Iqbal Awan ${ }^{1}$, Liaqat Ali ${ }^{3}$, \\ Sajid Fiaz ${ }^{4}$, Maria Naqve ${ }^{5}$, Muhammad Umair Hassan', Muhmmad Mansoor Javaid ${ }^{6}$, \\ Hongqin Wang ${ }^{7}$, Yang Shoujun ${ }^{7}$, Zhiyuan $\mathrm{Ma}^{7}$ \\ 'Department of Agronomy, University of Agriculture, 38040, Faisalabad, Pakistan. \\ ${ }^{2}$ College of Life Sciences, Yan'an University, Yan'an 716000, Shaanxi, China \\ ${ }^{3}$ Cholistan Institute of Desert Studies (CIDS), The Islamia University of Bahawalpur, Pakistan \\ ${ }^{4}$ Department of Plant Breeding and Genetics, The University of Haripur, 22620 Haripur, Pakistan \\ ${ }^{5}$ Department of Botany, Faculty of Sciences, University of Agriculture Faisalabad, Pakistan \\ ${ }^{6}$ Department of Agronomy, College of Agriculture, University of Sargodha, Sargodha, Pakistan \\ ${ }^{7}$ YanTai Institute, China Agriculture University, YanTai, China
}

Received: 28 August 2021

Accepted: 31 October 2021

\begin{abstract}
To ensure energy security and greenhouse gas emission, the world has decided to look for more sustainable and renewable energy sources. Biogas production from agricultural biomass is a fast growing market in the world. Suitable energy crops include maize, clover grass, alfalfa, sorghum, sudangrass, miscanthus and many others. Management considerations of energy crops such as harvesting time and nitrogen $(\mathrm{N})$ application considerably influenced the biomass yield, quality of crop along with bio-methane production. Therefore, field study was conducted to determine the impact of harvesting times (HT) and nitrogen rates on the biomass yield of maize and production of bio-methane from it. The variable NR and HT, had a substantial influence on morphological, and compositional traits and bio-methane production. The $\mathrm{N}$ application at $200 \mathrm{~kg} \mathrm{ha}^{-1}$ produced the taller plants, with maximum leaves, leaf area, biomass yield, protein contents, acid detergent fiber (ADF), neutral detergent fiber (NDF), and lignin contents. In addition to that higher nitrogen rate (200 $\left.\mathrm{kg} \mathrm{ha}^{-1}\right)$ produced higher methane production however, it remained the same with $150 \mathrm{~kg} \mathrm{~N} \mathrm{ha}^{-1}$. Harvesting at $65 \mathrm{DAS}$ produced the maximum taller plants with maximum leaf area, biomass yield and had maximum ADF and NDF which negatively affected the specific methane yield. Moreover, harvesting at 65 DAS produced maximum methane yield (MP) due to higher biomass yield (BY). It is concluded that $\mathrm{N}$ application
\end{abstract}

\footnotetext{
*e-mail: athar.mahmood@uaf.edu.pk
}

**e-mail: wangxiukang@yau.edu.cn 
(a) $150 \mathrm{~kg} \mathrm{ha}^{-1}$ and harvesting at 65 DAS can be suitable for getting the higher bio-methane production under semi-arid conditions of Pakistan.

Keywords: bio-methane, chemical composition, maize, nitrogen rate, harvesting time, warm and dry climate

\section{Novelty Statement}

In this paper we addressed the energy issues and potential solution for Pakistan using biomass of maize as feedstock for environment friendly and renewable energy by bio-methane production. We show that under warm and dry conditions of Pakistan, maize has considerable potential to develop as bio-energy crop, which can provide considerable greenhouse gases (GHG) benefits if its harvesting times and nitrogen rates are optimized.

This research article is quite fit for your esteemed journal as mitigation of GHG is need of the day in the scenario of climate change and global warming. By producing energy from renewable resources will help to reduce the GHG emission resulting in cleaner environment. Our work contributes to fill the gap of knowledge concerning crops for bio-energy in warm dry areas of the world.

\section{Introduction}

The increase in population and economic development increase energy demand and consumption worldwide [1]. Among renewable energy sources, fossil fuels are the major sources [2], however, these sources are continuously diminishing and resulted in greenhouse gasses emissions. To cope the issues of energy security and greenhouse gasses emissions, world have decided to look for more sustainable and renewable energy sources $[3,4]$. Plant biomass has been identified as sustainable and prime energy source globally [5]. Among sustainable sources, bio-energy crops with abundant biomass production can maintain the energy supply and can bring the reduction in greenhouse gasses emissions [6]. It is estimated that plant biomass can fulfill more the $14 \%$ energy demands globally. In addition, plant biomass can improve the farmer income with additional benefits of social and ecological sustainability.

Maize is one of the important crops that can be used for bio-energy production due its versatile nature, good biomass production and ability to grow in variety of climatic conditions [7]. Globally, it is cultivated on 177.5 million acres with production of 989.7 million tones [8]. Moreover, maize crop also produced same amount of residual biomass, that can be used for bio-energy production [9]. Maize was selected for this current research for biogas production due to its high DM yield and high methane productivity output per area unit [10]. Maize is easy to cultivate as its production technology is already well developed in Pakistan therefore, it can be easily adopted by the local farmers. In addition, it is tolerant to weeds, pests and diseases [11].

Harvesting time is one of the indispensable factors which considerably affected the quality and yield of biomass. Optimum harvest time substantially increased the protein content, while the delayed harvesting significantly increased the fiber contents [12] which ultimately affected the MP $[6,13,14]$. Likewise, delayed harvesting increased the biomass yield but decreased the biomass quality [15]. Generally, structural fiber and lignin contents and dry matter yield increased with prolonged maturity, conversely, protein contents and dry matter digestibility considerably reduced with advancing maturity $[16,17]$ which leads to reduction in the methane production [6].

Nitrogen $(\mathrm{N})$ is one of the most important nutrients, which significantly affect the growth and yield of maize crop. Nitrogen is a component of nucleic acid and protein and lower supply of nitrogen therefore significantly reduced the plant growth and biomass yield [18]. The optimum application of nitrogen has substantiated impact on the growth and biomass yield. Likewise, Ayeni and Adetunji [19] reported the significant difference in growth and yield due to different nitrogen rates. Many researchers also observed the significant increase in biomass yield with increasing rate of nitrogen application [18, 20] which may increase MP ha-1. Above mentioned information suggest that exploration of appropriate harvesting date and application of optimum $\mathrm{N}$ rate are key factor for successful biomethane production from maize as anaerobic digestion feedstock. Keeping in view the fact that most of research work have been done under temperate climate, whereas there is a lack of information on maize being cultivated for energy purpose under warm and dry climate, the current study was aimed to explore the impact of variable harvest date (HT) and nitrogen rate (NR) on plant morphology, biomass yield and composition, and bio-methane yield of maize cultivated under semi-arid conditions of Pakistan.

\section{Materials and Methods}

\section{Location}

The current investigation was performed at Post Graduate, Agriculture Research Station, University of Agriculture Faisalabad during 2018. The study site has warm and dry climate and falls in sub-tropical zone, moreover, the prevailing conditions during 
Table 1. Weather conditions during crop growth period.

\begin{tabular}{|c|c|c|c|}
\hline Month & $\begin{array}{c}\text { Aver. Temp } \\
\left({ }^{\circ} \mathrm{C}\right)\end{array}$ & $\begin{array}{c}\text { Rainfall } \\
(\mathrm{mm})\end{array}$ & $\begin{array}{c}\text { Relative Humidity } \\
(\%)\end{array}$ \\
\hline June & 27.3 & 41.6 & 44.5 \\
\hline July & 33.7 & 161.4 & 70 \\
\hline August & 33.4 & 66 & 68.9 \\
\hline
\end{tabular}

Table 2. Physio-chemical analysis of soil.

\begin{tabular}{|c|c|c|}
\hline Properties & Unit & $\begin{array}{c}\text { Value for Depth } \\
(0-25 \mathrm{~cm})\end{array}$ \\
\hline Available N & $\%$ & 0.037 \\
\hline Avail P & Ppm & 24.7 \\
\hline Available K & Ppm & 11.8 \\
\hline Organic matter & $\%$ & 0.82 \\
\hline $\mathrm{pH}$ & - & 7.77 \\
\hline EC & $\mathrm{ds} \mathrm{m}^{-1}$ & 1.03 \\
\hline Texture & \multicolumn{2}{|c|}{ Sandy Loam Soil } \\
\hline
\end{tabular}

study are presented in Table 1. The soil samples from different parts of experimental site were collected and homogenized to made composite sample and analyzed to determine different properties. The soil was loam and had $\mathrm{pH} 7.8$, organic matter $0.82 \mathrm{~g} \mathrm{~kg}^{-1}$, available $\mathrm{N} 0.37 \mathrm{~g} \mathrm{~kg}^{-1}$, P $6.79 \mathrm{mg} \mathrm{kg}^{-1}$ exchangeable potassium $188 \mathrm{mg} \mathrm{kg}^{-1}$ (Table 2).

\section{Crop Management}

The seed bed was prepared by ploughing the field two times followed by planking. Maize variety Sorgodha-2002 (Source, Fodder Research Institute Sargodha, Pakistan) was sown in $30 \mathrm{~cm}$ apart rows by using seed at the rate of $100 \mathrm{~kg} \mathrm{ha}^{-1}$. Sargodha 2002 variety was selected due to promising biomass potential with the ability to establish in various climatic and soil conditions. Phosphorous and potash fertilizers were used at $115-125 \mathrm{~kg} \mathrm{ha}^{-1}$, respectively and nitrogen was applied according to the treatments. The full dose of P (source was DAP) and K (source was SOP) was applied at the time of first irrigation. Pre-soaking irrigation was applied to bring the soil in workable position, after that two irrigations were applied at 20 and 40 days after sowing to the maize crop in both growing seasons. Other management practices were kept constant to get the good stand establishment and biomass yield.

\section{Experimental Design}

The experiment was laid out in randomized complete block design (RCBD) in factorial arrangement with four replications. The study was comprised of different harvesting times i.e., harvesting after 45, 55, 65 days of sowing (DAS) and nitrogen rates i.e., $\mathrm{N}_{0}=$ control (No $\mathrm{N}$ application), $\mathrm{N}_{1}=\mathrm{N} @ 100 \mathrm{~kg} \mathrm{ha}^{-1}, \mathrm{~N}_{2}=\mathrm{N} @$ $150 \mathrm{~kg} \mathrm{ha}^{-1}, \mathrm{~N}_{3}=\mathrm{N} @ 200 \mathrm{~kg} \mathrm{ha}^{-1}$.

\section{Observations and Measurements}

Ten plants were selected from each treatment to count leaves were and measured plant height was and leaf area per plant. The experimental plots were harvested and weight to determine the fresh biomass yield and a sub-sample was over dried $\left(70^{\circ} \mathrm{C}\right)$ to determine the dried biomass yield (DMY) and converted into $\mathrm{t} \mathrm{ha}^{-1}$. Leaf and stem biomass proportion was determined by the separation and dividing of relevant portion with total weight of sample. The dry matter percentage was calculated by the following formula: dry weight/fresh weight $\times 100$. Chlorophyll meter SPAD 502 Plus (Konica Minolta Sensing, Inc., Sakai, Osaka, Japan) was used to determine the chlorophyll contents. The collected maize samples were dried and grinded and ash, protein, and volatile solids contents were determined by the methods of AOAC [21] and fibers (ADF, NDF and ADL) were determined by the methods of Van Soest et al [22]. Bio-methane measurement was taken using Bioprocess Control's AMPTS equipment as described by Hassan et al. [14]. Liquid manure was taken as source of bacteria to digest the samples. The $16 \mathrm{~g}$ of maize samples were used in digester after that the total volume of digesters were made up to $400 \mathrm{ml}$, in the meanwhile, digesters were perched with $\mathrm{N}$ gas to produce the anaerobic conditions. The temperature of digesters was kept constant to $37^{\circ} \mathrm{C}$ by standing them in water bath. The samples were allowed to digest for 28 days. The bio-methane produced by each sample on each day was noted from connected computer operated systems.

\section{Statistical Analysis}

The collected data on biomass, compositional traits and methane yield were analyzed statistically by using the Fisher analysis of variance technique [23]. The least significant difference (LSD) test at (5\% probability) was used to sort out the difference among the treatments.

\section{Results}

\section{Growth Attributes}

The variable NR and HT clearly affected the growth and morphological traits (Table 3). The application of $200 \mathrm{~kg} \mathrm{~N} \mathrm{ha}^{-1}$ remained on top and it produced the tallest plants $(188 \mathrm{~cm})$ with more leaves (14.24) and leaf area per plant $\left(1872.77 \mathrm{~cm}^{2}\right)$ and chlorophyll contents $(35.02 \%)$, however, it remained similar with $150 \mathrm{~kg} \mathrm{~N} \mathrm{ha}{ }^{-1}$. Moreover, the no $\mathrm{N}$ application led 
Table 3. ANOVA sources, F values and levels of statistical significance in plant morphology and biomass yield.

\begin{tabular}{|c|c|c|c|c|c|c|c|c|}
\hline \multirow{2}{*}{ Source } & \multirow{2}{*}{ DF } & LPP & FY & DM & DMY & Chl. Cont & PH & LA \\
\cline { 3 - 9 } & & $($ Nos $)$ & $\left(\right.$ tha $\left.^{-1}\right)$ & $(\%)$ & $\left(\right.$ tha $\left.^{-1}\right)$ & $(\%)$ & $(\mathrm{cm})$ & $(\mathrm{cm} / \mathrm{cm})$ \\
\hline HT & 2 & $262.36^{* *}$ & $36.51^{* *}$ & $65.12^{*}$ & $65.12^{* *}$ & $16.39^{* *}$ & $106.62^{* *}$ & $43.15^{*}$ \\
\hline NR & 3 & $71.11^{* *}$ & $14.88^{* *}$ & $15.56^{\mathrm{NS}}$ & $15.56^{* *}$ & $3.67^{*}$ & $34.77^{* *}$ & $8.43^{*}$ \\
\hline HT X NR & 6 & $0.91^{\mathrm{NS}}$ & $1.43^{\mathrm{NS}}$ & $0.58^{\mathrm{NS}}$ & $0.58^{\mathrm{NS}}$ & $0.06^{\mathrm{NS}}$ & $0.79^{\mathrm{NS}}$ & $1.48^{\mathrm{NS}}$ \\
\hline
\end{tabular}

DF, degree of freedom, LPP, leaves per plant, FY, fresh yield, DM, dry matter, Chl, chlorophyll, Cont, content, PH, plant height, LA, leaf area, NS, * and $* *$ indicate not significant, significant at $\mathrm{P} \leq 0.05$ and $\mathrm{P} \leq 0.01$, respectively.

to production of shortest plant with minimum leaves, leaf area and chlorophyll contents (Table 4). Among harvesting times, tallest plants with more leaves with more leaf area was noted 65 DAS whilst maximum leaves and chlorophyll contents were noted 45 DAS (Table 4).

\section{Biomass Attributes}

Both $\mathrm{N}$ rates and $\mathrm{HT}$ factors markedly affected biomass distribution. Delayed harvesting produced clearly resulted in lower leaf biomass proportion compared to early harvesting. Increased $\mathrm{N}$ rates significantly enhanced leaf proportion (Fig. 1). Experimental data showed that delayed harvesting produced higher stem biomass proportion compared to early harvesting (Fig. 2). On the other hand, higher stem biomass proportion was gained when no $\mathrm{N}$ was applied compared to other $\mathrm{N}$ rates (Fig. 2). Experimental data showed that NR and HT had a clear impact on biomass yield and yield attributes of maize (Table 3). The $\mathrm{N}$ applied at $200 \mathrm{~kg} \mathrm{~N}^{-1}$ produced significantly higher fresh biomass (52.64 tha-1) and DM yield (14.17 t ha-1) and minimum fresh and DM yield was recorded without $\mathrm{N}$ application (Table 5). In the case of HT, maximum fresh biomass yield (53.77 $\left.\mathrm{t} \mathrm{ha}^{-1}\right)$ and DM yield (14.92t ha-1) was noticed at 65DAS and minimum was recorded at 45 DAS. The variable NR had no effect on the DM percentage, however, HT had a significant impact on the dry matter percentage with maximum DM content (27.89\%) that was recorded at 65DAS and minimum DM content (24.66\%) was determined at 45 DAS (Table 5).

\section{Biomass Composition}

ANOVA table indicates that NR and HT had a significant effect on chemical composition of maize (Table 6). Maximum ash (10.24\%), protein (11.84\%), ADF (26.89\%), NDF (49.31\%) and lignin contents were recorded with $\mathrm{N}$ application at $200 \mathrm{~kg} \mathrm{ha}^{-1}$ and minimum ash, ash, protein and fiber contents were recorded without $\mathrm{N}$ applications (Table 7). Regarding the fat, highest contents $(2.27 \%)$ were recorded in control treatment and minimum (1.99\%) was recorded with $200 \mathrm{~kg} \mathrm{~N} \mathrm{ha}^{-1}$ (data not given). Among HT, maximum ash, protein and fat contents were recorded at 45DAS and minimum was recorded at 65 DAS. With respect to harvesting times markedly higher ADF contents $(27.89 .34 \%)$ and NDF (54.37\%) were determined at 65DAS while the lowest value was observed at 45DAS (Table 7). Lignin content increased with delayed harvesting compared to early harvesting. Regarding

Table 4. Effect variable nitrogen rates and harvesting times on plant height, leaves per plant, leaf area per plant and chlorophyll contents.

\begin{tabular}{|c|c|c|c|c|}
\hline Nitrogen rates & Plant height $(\mathrm{cm})$ & Leaves per plant & Leaf area per plant & Chlorophyll contents \\
\hline $0 \mathrm{~kg} \mathrm{ha}^{-1}$ & 159D & $12.00 \mathrm{C}$ & 1700B & $29.13 \mathrm{C}$ \\
\hline $100 \mathrm{~kg} \mathrm{ha}^{-1}$ & $171 \mathrm{C}$ & $13.43 \mathrm{~B}$ & 1768.33B & $32.11 \mathrm{~B}$ \\
\hline $150 \mathrm{~kg} \mathrm{ha}^{-1}$ & 181B & $14.07 \mathrm{~A}$ & $1861.55 \mathrm{~A}$ & $34.87 \mathrm{~A}$ \\
\hline $200 \mathrm{~kg} \mathrm{ha}^{-1}$ & $188 \mathrm{~A}$ & $14.24 \mathrm{~A}$ & $1872.77 \mathrm{~A}$ & $35.02 \mathrm{~A}$ \\
\hline LSD P $\leq 0.05$ & 6.27 & 0.35 & 82.64 & 1.63 \\
\hline \multicolumn{5}{|c|}{ Harvesting times } \\
\hline 45DAS & $155 \mathrm{C}$ & $14.99 \mathrm{~A}$ & $1671.33 \mathrm{C}$ & $33.61 \mathrm{~A}$ \\
\hline 55DAS & 177B & 13.7B & 1750.66B & $33.01 \mathrm{AB}$ \\
\hline 65DAS & $193 \mathrm{~A}$ & $11.62 \mathrm{C}$ & $1980 \mathrm{~A}$ & $31.85 \mathrm{~B}$ \\
\hline LSD $\mathrm{P} \leq 0.05$ & 5.43 & 0.31 & 71.57 & 1.41 \\
\hline
\end{tabular}

Means sharing different letter differed at 0.05 probability level 
Table 5. Effect of variable nitrogen rates and harvesting times on fresh biomass, biomass yield and DM content .

\begin{tabular}{|c|c|c|c|}
\hline Nitrogen rates & $\begin{array}{c}\text { Fresh Biomass Yield } \\
\left(\mathrm{t} \mathrm{ha}^{-1}\right)\end{array}$ & $\begin{array}{c}\text { Biomass Yield } \\
\left(\mathrm{t} \mathrm{ha}^{-1}\right)\end{array}$ & $\begin{array}{c}\text { DM Content } \\
(\%)\end{array}$ \\
\hline $0 \mathrm{~kg} \mathrm{ha}^{-1}$ & $41.57 \mathrm{C}$ & $9.08 \mathrm{C}$ & 26.50 \\
\hline $100 \mathrm{~kg} \mathrm{ha}^{-1}$ & $47.67 \mathrm{~B}$ & $12.55 \mathrm{~B}$ & 26.45 \\
\hline $150 \mathrm{~kg} \mathrm{ha}^{-1}$ & $52.04 \mathrm{~A}$ & $14.26 \mathrm{~A}$ & 26.89 \\
\hline $200 \mathrm{~kg} \mathrm{ha}^{-1}$ & $52.64 \mathrm{~A}$ & $14.57 \mathrm{~A}$ & \multicolumn{2}{|c|}{ NS } \\
\hline LSD P $\leq \mathbf{0 . 0 5}$ & $\mathbf{3 . 8 9}$ & $\mathbf{1 . 0 6}$ & $24.66 \mathrm{~B}$ \\
\hline \multicolumn{2}{|c|}{ Harvesting times } & $10.83 \mathrm{C}$ \\
\hline $45 \mathrm{DAS}$ & $40.62 \mathrm{~B}$ & $13.82 \mathrm{~B}$ & $26.50 \mathrm{AB}$ \\
\hline 55DAS & $51.04 \mathrm{~A}$ & $15.26 \mathrm{~A}$ & $27.89 \mathrm{~A}$ \\
\hline 65DAS & $53.77 \mathrm{~A}$ & $\mathbf{0 . 9 2}$ & $\mathbf{0 . 9 2}$ \\
\hline
\end{tabular}

Means sharing different letter differed at 0.05 probability level
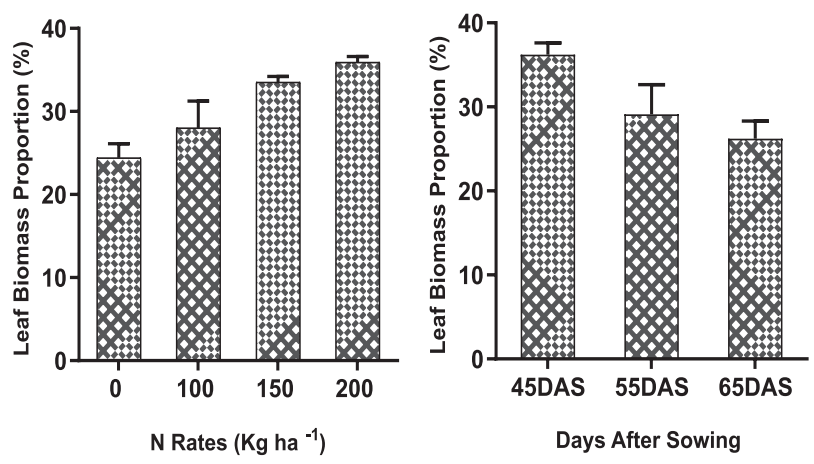

Fig. 1. Effect of different HT and NR on leaf biomass proportion of maize. Bars on the graphs representing standard deviation.

volatile solid, all $\mathrm{N}$ rates exhibited comparable values. On the contrary, significantly higher volatile solids (VS) contents were determined with delayed harvesting (Fig. 3)

\section{Bio-Methane Production}

The advancing in harvesting time decreased the specific methane yield (SMY) yield per $\mathrm{kg}$ DM.
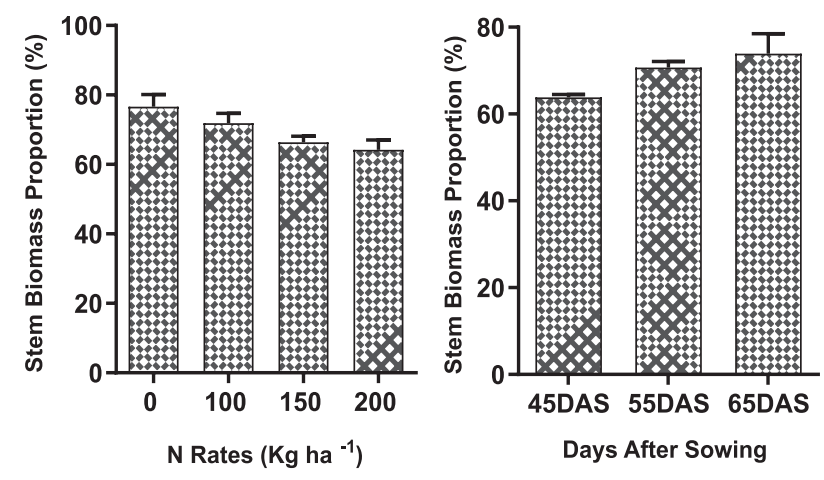

Fig. 2. Effect of different HT and NR on stem biomass proportion of maize. Bars on the graphs representing standard deviation.

However, advancing in HT increased the MY $\mathrm{ha}^{-1}$ due to the increase in DMY (Fig. 4). The delayed harvesting produced significantly higher bio-methane compared to early harvesting time. Nitrogen rates also showed clear difference for methane productivity as higher levels application of $\mathrm{N}$ produced the maximum bio-methane production owing to higher DM yield as compared to other level tested in the experiment (Fig. 5).

Table 6. ANOVA sources, F values and levels of statistical significance in fibre composition and methane output.

\begin{tabular}{|c|c|c|c|c|c|c|c|c|c|}
\hline Source & DF & XP & Ash & ADF & NDF & ADL & VS & SMY & MY \\
\hline & & $(\%)$ & $(\%)$ & $(\%)$ & $(\%)$ & $(\%)$ & $(\%)$ & $(\mathrm{NL} / \mathrm{Kg} \mathrm{VS})$ & $\mathrm{Nm} / \mathrm{ha}$ \\
\hline HT & 2 & $118.23^{* *}$ & $43.51^{* *}$ & $183.21^{* *}$ & $166.88^{* *}$ & $118.21^{* *}$ & $173.36^{* *}$ & $453.22^{* *}$ & $273.53^{* *}$ \\
\hline NR & 3 & $143.28^{* *}$ & $15.06^{* *}$ & $25.53^{* *}$ & $16.08^{* *}$ & $21.11^{* *}$ & $29.23^{* *}$ & $47.65^{* *}$ & $18.75^{* *}$ \\
\hline HT X NR & 6 & $0.8^{\mathrm{NS}}$ & $0.42^{\mathrm{NS}}$ & $0.47^{\mathrm{NS}}$ & $0.91^{\mathrm{NS}}$ & $0.73^{\mathrm{NS}}$ & $1.45^{*}$ & $19.5^{* *}$ & $17.81^{* *}$ \\
\hline
\end{tabular}

DF, degree of freedom, XP, protein content, ADF, acid detergent fibre, NDF, neutral detergent fibre, ADL, lignin, VS, volatile solid, SMY, specific methane yield, MY, methane yield, ${ }^{\mathrm{NS}},{ }^{*}$ and ** indicate not significant, significant at $\mathrm{P} \leq 0.05$ and $\mathrm{P} \leq 0.01$, respectively. 
Table 7. Effect variable nitrogen rates and harvesting times on ash, protein, acid detergent fiber (ADF) and neutral detergent fiber (NDF) contents.

\begin{tabular}{|c|c|c|c|c|c|}
\hline Nitrogen rates & Ash (\%) & Protein $(\%)$ & $\operatorname{ADF}(\%)$ & NDF (\%) & $\mathrm{ADL}$ \\
\hline $0 \mathrm{~kg} \mathrm{ha}^{-1}$ & $8.94 \mathrm{C}$ & $9.01 \mathrm{D}$ & $26.5 \mathrm{~B}$ & $42.18 \mathrm{C}$ & $5.3 \mathrm{C}$ \\
\hline $100 \mathrm{~kg} \mathrm{ha}^{-1}$ & $9.24 \mathrm{BC}$ & $9.46 \mathrm{C}$ & $25.45 \mathrm{AB}$ & $46.24 \mathrm{~B}$ & $5.9 \mathrm{~B}$ \\
\hline $150 \mathrm{~kg} \mathrm{ha}^{-1}$ & $9.64 \mathrm{~B}$ & $10.53 \mathrm{~B}$ & $26.56 \mathrm{~A}$ & $47.68 \mathrm{AB}$ & $5.7 \mathrm{~B}$ \\
\hline $200 \mathrm{~kg} \mathrm{ha}^{-1}$ & $10.24 \mathrm{~A}$ & $11.84 \mathrm{~A}$ & $26.89 \mathrm{~A}$ & $49.31 \mathrm{~A}$ & $6.8 \mathrm{~A}$ \\
\hline LSD P $\leq 0.05$ & 0.43 & 0.31 & NS & 2.23 & 0.4 \\
\hline \multicolumn{6}{|c|}{ Harvesting times } \\
\hline 45DAS & $10.32 \mathrm{~A}$ & $11.25 \mathrm{~A}$ & $24.66 \mathrm{~B}$ & $37.43 \mathrm{C}$ & $4.9 \mathrm{C}$ \\
\hline 55DAS & $9.55 \mathrm{~B}$ & $10.13 \mathrm{~B}$ & $26.5 \mathrm{AB}$ & $47.26 \mathrm{~B}$ & $5.7 \mathrm{~B}$ \\
\hline 65DAS & $8.67 \mathrm{C}$ & $9.27 \mathrm{C}$ & $27.89 \mathrm{~A}$ & $54.37 \mathrm{~A}$ & $7.1 \mathrm{~A}$ \\
\hline LSD $P \leq 0.05$ & 0.37 & 0.27 & 0.92 & 1.93 & 1.3 \\
\hline
\end{tabular}

Means sharing different letter differed at 0.05 probability level
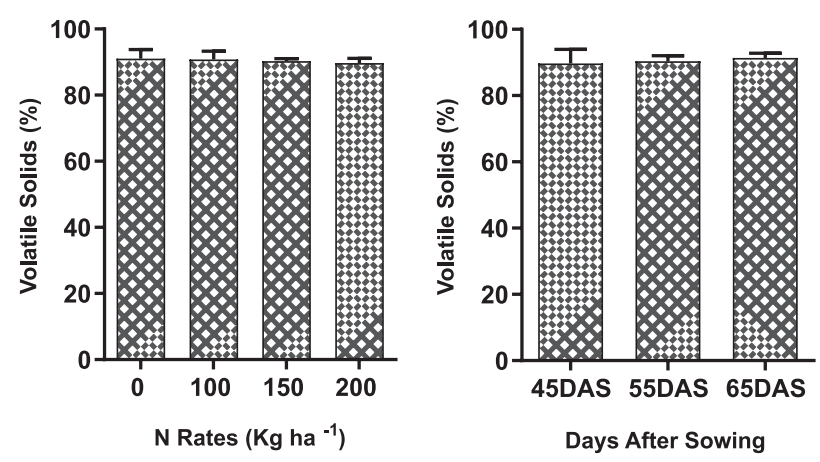

Fig. 3. Effect of different HT and NR on volatile solids of maize. Bars on the graphs representing standard deviation.

\section{Discussion}

The increase in plant height by $\mathrm{N}$ application can be ascribed to fact that $\mathrm{N}$ considerably improves plant growth, length of internodes which resulted in a significant increase in plant height $[24,25]$. The plant height increased progressively due to intermodal distance which in turns increased the stem elongation and therefore increased the plant height.

The enlarged leaf area with increase in $\mathrm{N}$ rates can be due to rapid and active cell multiplication within plant leaves which resulted in production of more leaves with larger leaf blades and therefore higher leaf area plant [26]. At earlier stage of harvesting leaves were smaller with minimum length and width, therefore had minimum leaf area per plant. On the other hand, with advancing maturity the leaves length and width was increased therefore plants had more leaf area at later harvesting stages. These results are same as reported by Botha and Rethman [27] as they reported that delayed harvesting increased the leaf area, further they also found maximum leaf area per plant at 65 DAS.
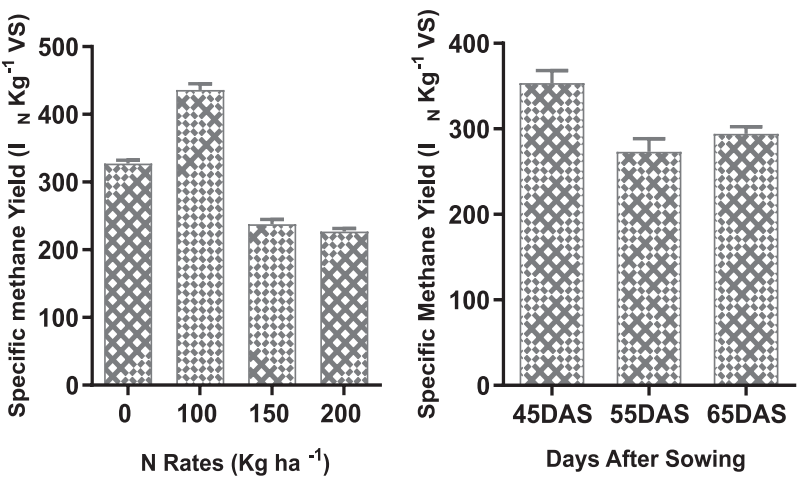

Fig. 4. Effect of different HT and NR on specific methane yield $\left(1_{\mathrm{N}} \mathrm{kg}^{-1} \mathrm{VS}\right)$ of maize. Bars on the graphs representing standard deviation.
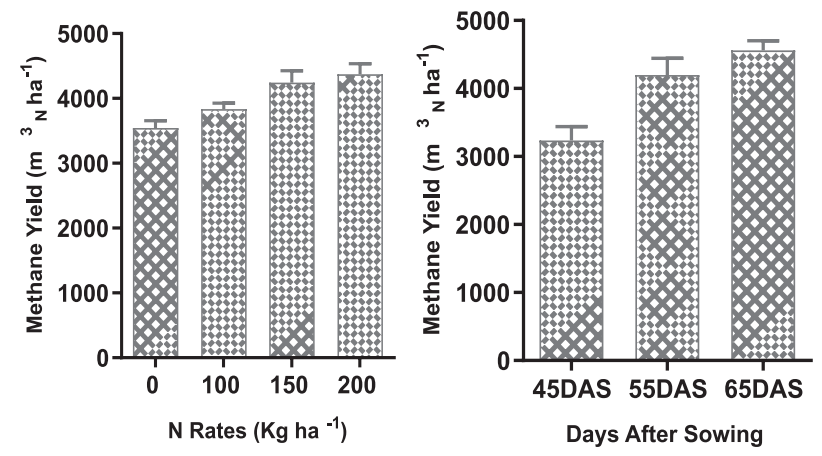

Fig. 5. Effect of different HT and NR on methane production $\left(\mathrm{m}^{3} \mathrm{~N} \mathrm{ha}^{-1}\right)$ of maize. Bars on the graphs representing standard deviation.

Nitrogen application remarkably increased the fresh biomass yield. The maximum fresh biomass yield with application of higher NR can be ascribed to lucrative consumption of applied nitrogen and other allied 
environmental resources by the maize crop which resulted in maximum biomass yield. Likewise, Biswas and $\mathrm{Ma}$ [28] also found the significant effect of NR on biomass yield of maize crop. They also observed the maximum biomass yield with application of $\mathrm{N}$ at $200 \mathrm{~kg}$ $\mathrm{ha}^{-1}$. The increase in fresh biomass yield with advancing maturity can be ascribed to increase in plant height, stem length and increase in leaf area per plant which captured the more light and produced more assimilates for plant utilization which led to remarkable increase in the fresh biomass production. Previous observations also showed that biomass production increased with delayed harvesting owing to the increase in plant height, and plant weight [29]. Similarly, both NR and HT had substantiated influence on the DM yield. The increase in NR improved the plant growth, per plant weight, leaves area per plant and plant height which resultantly increased the DM yield as compared to lower NR. Similarly, Cerny et al. [30] also noted that dry matter yield increased linearly with increase in NR. The progressive increase in dry matter yield can be ascribed to increase in plant height, per plant weight and fresh forage yield which consequently increased the dry matter yield. Therefore, detecting the most suitable HT is a crucial step to optimize crop management for bio-energy uses. The progressive increase in the DM over the time is quite commonly documented in the literature $[6,29,31]$. Ram et al. [31] also found that delaying harvesting considerably increased the DM yield.

NR rate also had significant impact on ash contents. The increase in ash contents with increase in NR can be due to higher DM production in plants that contributed directly or indirectly in biosynthesis of minerals. The ash contents decreased significantly with advancing maturity which might to translocation of minerals from the plant leaves to reproductive parts before shedding [6].

The maximum protein contents were observed at 45 DAS, because at that stage plant had more leaves as compared to other harvesting times. Moreover, leaves are considered to be richer in protein as compared to other plant parts, thus more protein contents were noted at 45 DAS. The leaves per plant were decreased with advancing maturity therefore protein contents were decreased with advancing maturity. Moreover, Chattha et al. [29] also noted a significant decrease in protein concentration with advancing maturity.

The increase in NR considerably increased the fibers (ADF, NDF and lignin) contents as compared to no $\mathrm{N}$ application. The increase in NR increased the stem diameter and plant height which resulted in a considerable increase in fiber contents, as stem has more fiber content as compared to leaves and panicles Similarly, Aslam et al. [32] also found significant increase in crude fiber contents with increase $\mathrm{N}$ application rates. Moreover, the fiber fractions (ADF and NDF) also increased progressively with time and maximum was noticed 65DAS. The ADF and NDF are components of secondary cell wall, as the cell wall thickness increased with advancing of maturity therefore concentration of ADF also increased with advancing maturity. The increase in fiber fractions over the time has been widely documented in literature $[6,17]$.

Specific methane yield (SMY) plays a core role in the final MY. The fiber fractions considerably affect the DM digestibility which in turns affects the SMY. The lowest SMY was noted with higher NR and later harvesting (65DAS) which was due to higher ADF, NDF and lignin contents which reduces the DM digestibility and thus led to lower SMY [33]. In contrast to higher SMY with lower NR and earlier HT was due to lower ADF and NDF and higher protein and fat which increases the biomass digestibility and thus produced more specific methane. The MY is a product of SMY and dry matter yield. The maximum MY was determined with higher NR and later harvesting (65DAS). The maximum DM yield was noted higher NR and harvesting 65DAS which result in more MY ha ${ }^{-1}$ as compared to other NR and HT.

\section{Conclusion}

The optimization of NR and HT are the imperative factor to get the good biomass and renewable and environment friendly energy source in the form of bio-methane. The $\mathrm{N}$ application applied at $200 \mathrm{~kg} \mathrm{ha}^{-1}$ produced maximum biomass yield and MY, however, it remained same with $150 \mathrm{~kg} \mathrm{~N} \mathrm{ha}{ }^{-1}$. Moreover, harvesting 65DAS was obviously better owing to higher biomass and MY. Therefore, $\mathrm{N}$ application at $150 \mathrm{~kg} \mathrm{ha}^{-1}$ and harvesting 65DAS may be suitable for getting the higher biomass and bio-methane production under warmer dry conditions of Pakistan.

\section{Conflict of Interest}

The authors have no conflict of interest to disclose.

\section{Funding}

The publication of the present work is supported by the Natural Science Basic Research Program of Shaanxi Province (grant no. 2018JQ5218) and the National Natural Science Foundation of China (51809224), Top Young Talents of Shaanxi Special Support Program.

\section{Acknowledgment}

We thank University of Agriculture Faisalabad (UAF) for providing infrastructure during this research. 


\section{References}

1. ZAMAN K., ABD-EL MOEMEN M. Energy consumption, carbon dioxide emissions and economic development: evaluating alternative and plausible environmental hypothesis for sustainable growth. Renewable and Sustainable Energy Reviews, 74, 1119, 2017.

2. MAHMOOD A., WANG X., SHAHZAD A.N., FIAZ S., ALI H., NAQVE M., JAVAID M.M., MUMTAZ S., NASEER M., DONG R. Perspectives on Bioenergy Feedstock Development in Pakistan: Challenges and Opportunities. Sustainability, 13, 8438, 2021.

3. RATHORE P.K.S., CHAUHAN D.S., SINGH R.P. Decentralized solar rooftop photovoltaic in India: On the path of sustainable energy security. Renewable energy, 131, 297, 2019.

4. LUCAS J.N.V., FRANCÉS G.E., GONZÁLEZ E.S.M. Energy security and renewable energy deployment in the EU: Liaisons dangereuses or virtuous circle? Renewable and sustainable energy reviews, 62, 1032, 2016.

5. SANSANIWAL S., ROSEN M., TYAGI S. Global challenges in the sustainable development of biomass gasification: An overview. Renewable and Sustainable Energy Reviews, 80, 23, 2017.

6. HASSAN M.U., CHATTHA M.U., BARBANTI L., CHATTHA M.B., MAHMOOD A., KHAN I., NAWAZ M. Combined cultivar and harvest time to enhance biomass and methane yield in sorghum under warm dry conditions in Pakistan. Industrial Crops and Products, 132, 84, 2019.

7. SRIVASTAVA R.K. Bio-Energy production by contribution of effective and suitable microbial system. Materials Science for Energy Technologies, 2, 308, 2019.

8. ALLEN E., VALDES C. Brazil's corn industry and the effect on the seasonal pattern of US corn exports; United States Department of Agriculture, Economic Research Service: 2016.

9. SU C.W., WANG X.Q., TAO R., OANA-RAMONA L. Do oil prices drive agricultural commodity prices? Further evidence in a global bio-energy context. Energy, 172, 691, 2019.

10. JANKOWSKI K.J., DUBIS B., SOKÓLSKI M.M., ZAŁUSKI D., BÓRAWSKI P., SZEMPLIŃSKI W. Productivity and energy balance of maize and sorghum grown for biogas in a large-area farm in Poland: An 11year field experiment. Industrial Crops and Products, 148, 112326, 2020.

11. ALTIERI M.A., NICHOLLS C.I., HENAO A., LANA M.A. Agroecology and the design of climate changeresilient farming systems. Agronomy for sustainable development, 35, 869, 2015.

12. SALAMA H.S.A. Yield and nutritive value of maize (Zea mays L.) forage as affected by plant density, sowing date and age at harvest. Italian Journal of Agronomy, 14, 114, 2019.

13. MAHMOOD A., HUSSAIN A., SHAHZAD A.N., HONERMEIER B. Biomass and biogas yielding potential of sorghum as affected by planting density, sowing time and cultivar. Pakistan Journal of Botany, 47, 2401, 2015.

14. HASSAN M.U., CHATTHA M.U., MAHMOOD A., SAHI S.T. Performance of sorghum cultivars for biomass quality and biomethane yield grown in semi-arid area of Pakistan. Environmental Science and Pollution Research, 25, 12800, 2018.

15. KNOLL J.E., JOHNSON J.M., HUANG P., LEE R.D., ANDERSON W.F. Effects of delayed winter harvest on biomass yield and quality of napiergrass and energycane. Biomass and Bioenergy, 80, 330, 2015.

16. HASSAN M., CHATTHA M., CHATTHA M., MAHMOOD A., SAHI S. Impact of harvesting times on chemical composition and methane productivity of sorghum (Sorghum bicolor Moench L.). Applied Ecology and Environmental Research, 16, 2267, 2018.

17. ATIS I., KONUSKAN O., DURU M., GOZUBENLI H., YILMAZ S. Effect of harvesting time on yield, composition and forage quality of some forage sorghum cultivars. International Journal of Agriculture and Biology, 14, 2012.

18. LEGHARI S.J., WAHOCHO N.A., LAGHARI G.M., HAFEEZLAGHARI A., MUSTAFABHABHAN, G., HUSSAINTALPUR K., BHUTTO, T.A., WAHOCHO, S.A., LASHARI A.A. Role of nitrogen for plant growth and development: A review. Advances in Environmental Biology, 10, 209, 2016.

19. ALMAZ M., HALIM R., MARTINI M., SAMSURI A. Integrated application of poultry manure and chemical fertiliser on soil chemical properties and nutrient uptake of maize and soybean. Malaysian Journal of Soil Science, 21, 13, 2017.

20. OBI M., EBO P. The effects of organic and inorganic amendments on soil physical properties and maize production in a severely degraded sandy soil in southern Nigeria. Bioresource Technology, 51, 117, 1995.

21. CHEMISTS A.O.O.A., HORWITZ W. Official methods of analysis; Association of Official Analytical Chemists Washington, DC: 1975; Volume 222.

22. VAN SOEST P.J. Nutritional ecology of the ruminant; Cornell university press: 1994.

23. D STEEL R.G., TORRIE J.H. Principles and procedures of statistics: a biometrical approach; McGraw-Hill: 1986.

24. MAHMUD K., AHMAD I., AYUB M. Effect of nitrogen and phosphorus on the fodder yield and quality of two sorghum cultivars (Sorghum bicolor L.). International Journal of Agriculture and Biology, 5, 61, 2003.

25. AYUB M., NADEEM M.A., TANVEER A., TAHIR M., KHAN R. Interactive effect of different nitrogen levels and seeding rates on fodder yield and quality of pearl millet. Pakan Journal Agriculture Sciences, 44, 592, 2007.

26. ALI N., ANJUM M.M. Effect of different nitrogen rates on growth, yield and quality of maize. Middle East J. Agric. Res, 6, 107, 2017.

27. BOTHA L., RETHMAN N. Yield and chemical coposition of Pennisetum glaucum L. at different cutting frequencies. Applied Plant Science, 8, 37, 1995.

28. BISWAS D.K., MA B.L. Effect of nitrogen rate and fertilizer nitrogen source on physiology, yield, grain quality, and nitrogen use efficiency in corn. Canadian Journal of Plant Science, 96, 392, 2016.

29. CHATTHA M.U., IQBAL A., HASSAN M.U., CHATTHA M.B., ISHAQUE W. USMAN M., KHAN S., FAYYAZ M.T., ULLAH M.A. Forage yield and quality of sweet sorghum as influenced by sowing methods and harvesting times. Journal of Basic and Applied Sciences, 13, 301, 2017.

30. ČERNÝ J., BALÍK J., KULHÁNEK M., VAŠÁK F., PEKLOVÁ L., SEDLÁŘ O. The effect of mineral $\mathrm{N}$ fertiliser and sewage sludge on yield and nitrogen efficiency of silage maize. Plant, Soil and Environment, 58, 76, 2012. 
31. RAM S., SINGH B. Growth, yield and quality of forage sorghum as affected by intercrop, harvesting time and nitrogen. Indian J. Dryland Agric. Res. \& Dev, 18, 167, 2003.

32. ASLAM M., IQBAL A., ZAMIR M.I., MUBEEN M., AMIN M. Effect of different nitrogen levels and seed rates on yield and quality of maize fodder. Crop Environment, 2, 47, 2011.
33. VON COSSEL M., MÖHRING J., KIESEL A., LEWANDOWSKI I. Optimization of specific methane yield prediction models for biogas crops based on lignocellulosic components using non-linear and cropspecific configurations. Industrial Crops and Products, 120, 330, 2018 